\title{
Ground Magnetic Investigation of Iron Occurrence in the Basement Rocks ofDadoru and Environs, Adamawa Massif, North East Nigeria
}

\author{
Yusuf.A, ${ }^{1}$ Bassey.N.E, ${ }^{2}$ Barka. $\mathrm{J}^{1}$ andYero.U. $\mathrm{Y}^{3}$ \\ ${ }^{I}$ Geology Department, Gombe State University, P.M.B.0127, Gombe, Nigeria \\ ${ }^{2}$ Geology Department, Akwalbom State University, MkpatEnin, P.M.B.1167, Uyo, Nigeria \\ ${ }^{3}$ Geology Programme, AbubakarTafawaBalewa University, P.M.B.0248,Bauchi, Nigeria
}

\begin{abstract}
The study area is located in the northwestern part of the Adamawa massif of northeastern Nigeria and lies between longitude $11^{\circ} 50^{\prime} \mathrm{E}$ and $12^{\circ} 00^{\prime} \mathrm{E}$ and latitude $8^{\circ} 49^{\prime} \mathrm{N}$ and $8^{\circ} 55^{\prime} \mathrm{N}$. Lithologies of the area include: granite-gneisses, porphyritic granites, and biotite hornblende gneiss. A G-856 Memory-Mag TM proton precision magnetometer was used to acquire ground magnetic data of the area following a regular grid pattern. The magnetic data were subjected to diurnal correction and contoured using Surfer 11surface mapping software to produce a magnetic map. Areas characterized by anomalous magnetic values (34342 -34348 nT) are interpreted as areas of iron occurrences. The computer software WingLink was been used to generate 2-D subsurface geologic models for the computation of the depths to the anomalous bodies. The average depth to the source of anomalous bodies is $351.67 \mathrm{~m}$, which is interpreted as average depth to iron mineral occurrence. Ground geologic mapping confirmed areas of surface iron occurrences as veins in granite gneiss. Geological investigation of the discovery is suggested to determine the tenor and tonnage for possible economic exploitation as part of Nigeria's government plan to revitalize the solid mineral/mining industry.
\end{abstract}

Keywords: Basement Complex, geological mapping, geomagnetic modelling, iron mineralization, Magnetic anomalies.

\section{Introduction}

The study area Dadoru and environs is located in the western part of the Adamawa massifs of northeastern Nigeria and lies between longitudes $11^{\circ} 50^{\prime}$ and $12^{\circ} \mathrm{E}$ and latitudes $8^{0} 49^{\prime}$ and $8^{0} 55^{\prime} \mathrm{N}$ (Fig.1). It covers a total area of $205.35 \mathrm{~km} 2$. The area is found on topographic map of Nigeria, Monkin Area with index/sheet no: 216, (scale of 1:100,000) published by the [1]. The area is drained by a number of rivers such as Rivers Tuwan, Kasale, Belwa, Vanmu, Yuwel and Darado. Climatic condition prevailing on the area is typical of northern part of Nigeria (characterized by both dry and wet seasons of about six months each in duration).

Interest in this work came from the second author who discovered slag from iron ore smelted by some indigenes of Gerei area of Adamawa State during one of his geological outings. This discovery was followed up by the first and third author through consultation of a book published by the Adamawa State Ministry of Commerce, Industries and Solid Minerals development, entitled; "Adamawa Solid minerals"(undated), and personal discussion with geological personnel in Adamawa state. Information about the iron mineral occurrence around Mayo-Belwaareas of the Adamawa Massif was got. The reported case of iron occurrences within the crystalline rocks of Dadoru and environs (Mayo - Belwa) did not shed more light on the information regarding the areal extent and the depth to the source of this mineralization. Hence, the need for a more comprehensive geophysical investigation of the area, that involves the use of ground magnetic technique in obtaining the earlier mentioned information (parameters).

The project design was done by the second author and executed by the first. Reconnaissance survey of the area was carried out, followed by geological mapping. This research was conducted with the objectives of producing a total magnetic intensity (TMI) map of the study area, identifying the area of iron mineralization based on anomalous values of the magnetic field, and determining the depths of occurrence of the iron ore from the magnetic data. The geological map generated helped to interpret the magnetic data. 


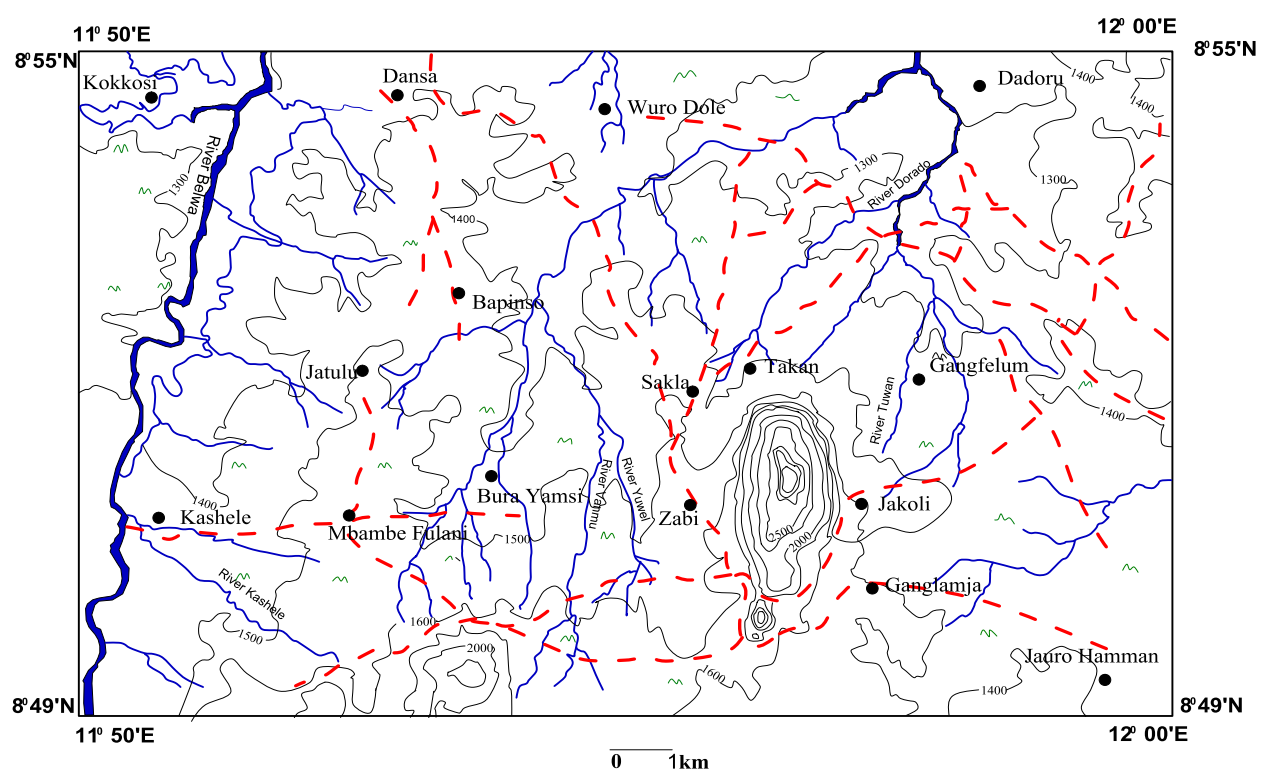

LEGEND:

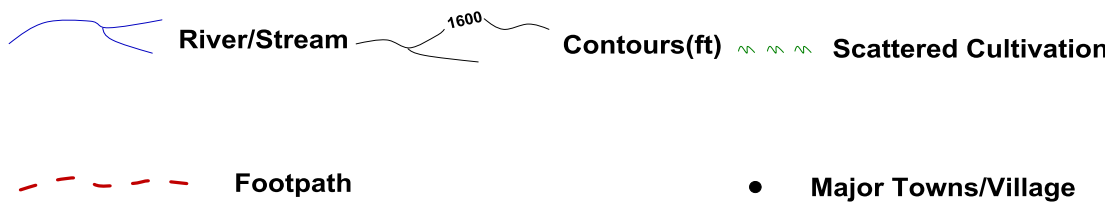

Figure1. topographicmap of the study area (after [1]).

\section{Ground Magnetic Method}

Magnetics is a geophysical survey technique that exploits the considerable differences in the magnetic properties of minerals with the ultimate objective of characterizing the earth's sub-surface. The technique requires the acquisition of measurements of the Amplitude of the Magnetic field at discrete points along survey lines distributed regularly throughout the area of interest [2]. The magnetic field, whose amplitude is measured, is the vector sum of; the Earth's main field which originates from dynamo action of conductive fluids in the Earth's deep interior [3]; An Induced field caused by magnetic induction in magnetically susceptible earth materials polarized by the main field [4]. A field caused by remanent magnetism of earth materials [4]; and Other (usually) less significant fields caused by solar, atmospheric and cultural influences [5]. It is the induced and remanant fields that are of particular interest to the regolith geoscientists because the magnitudes of these are directly related to the magnetic susceptibility, spatial distribution and concentration of local crustal materials. Fortunately, only few minerals occur abundantly enough in nature to make a significant contribution to the induced and remament fields. The most important of these is magnetite and to a lesser extent ilmenite and pyrrhotite ([6],[5].).

\section{Geology Of The Study Area}

The results obtained from the geological mapping exercise in the area revealed that the area is underlain by three major rock types which include porphyritic granites, biotite-hornblende gneiss and granite gneiss (Fig.2). Iron occurs as mineralized veins in the granite gneiss (Plate I, Fig.3). The porphyritic granite dominates the northwestern part of the study area (Fig. 2.), and constitutes about $40 \%$ of the total area. The porphyritic granite has large pinkish to whitish prismatic feldspar crystals as phenocrysts. It has numerous mineralized veins and joints whose dominant trend is NNE - SSW. The central, northeastern, southwestern, and southern parts of the mapped area are underlain by a granite-gneiss rock (Fig. 2). This rock type is metamorphosed and is considered to have been affected by more than one thermo-tectonic event [7]. The granite gneisses constitute about $50 \%$ of the lithologies of the area and consist of minerals like biotite and feldspars. It has foliation whose major trend is mainly NNE - SSW. Another metamorphic rock found in the eastern part of the area of study is the biotite-hornblende gneiss, which constitutes about 5\% of the total area of study (Fig.2). This is a highly foliated rock (Plate II), it is well exposed along stream channels in the study area. The foliation trends mainly in the ENE - WSW direction. 

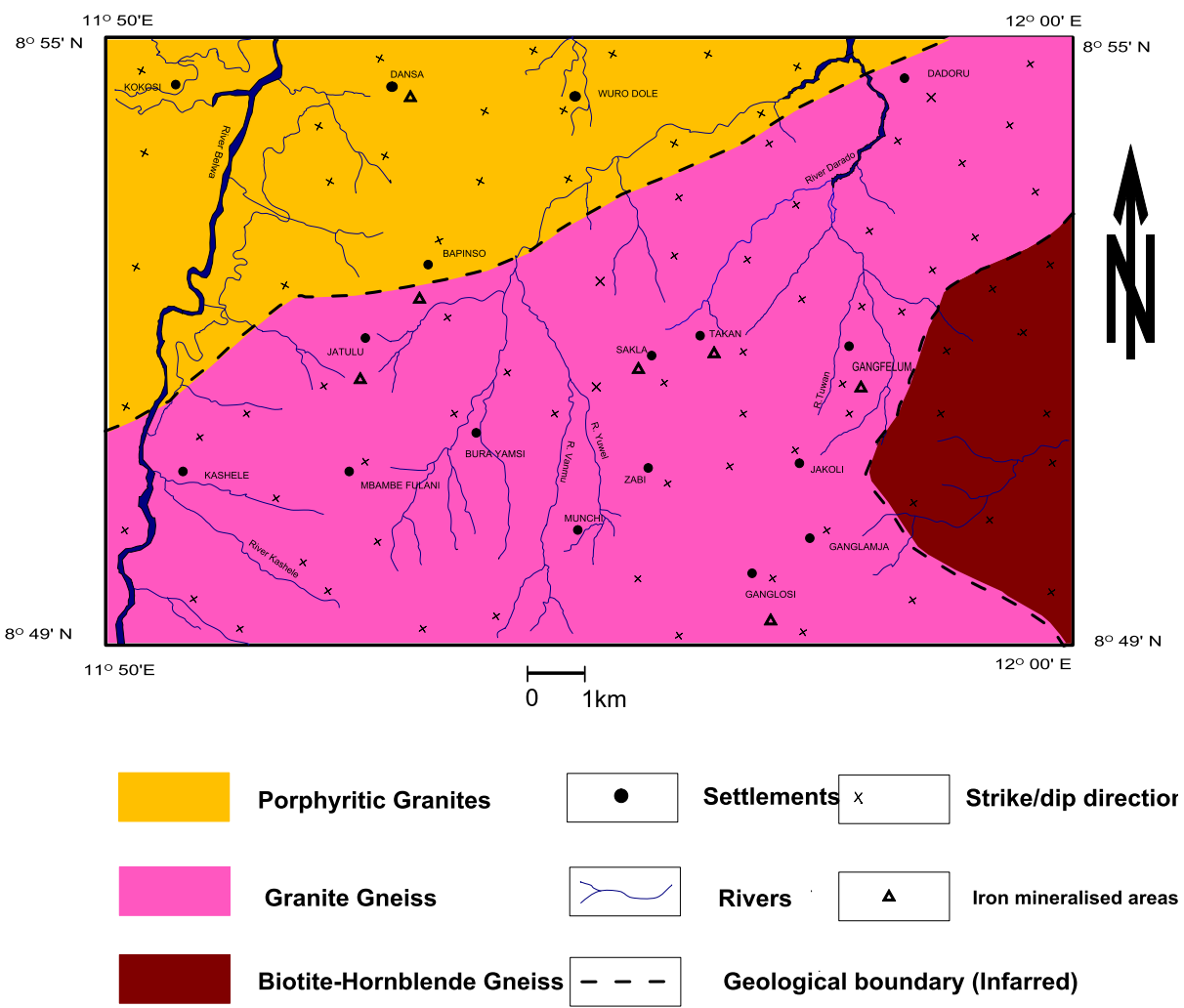

Figure 2: Geology of Dadoru and environs (part of Adamawa massifs) northeastern Nigeria (from the present study).

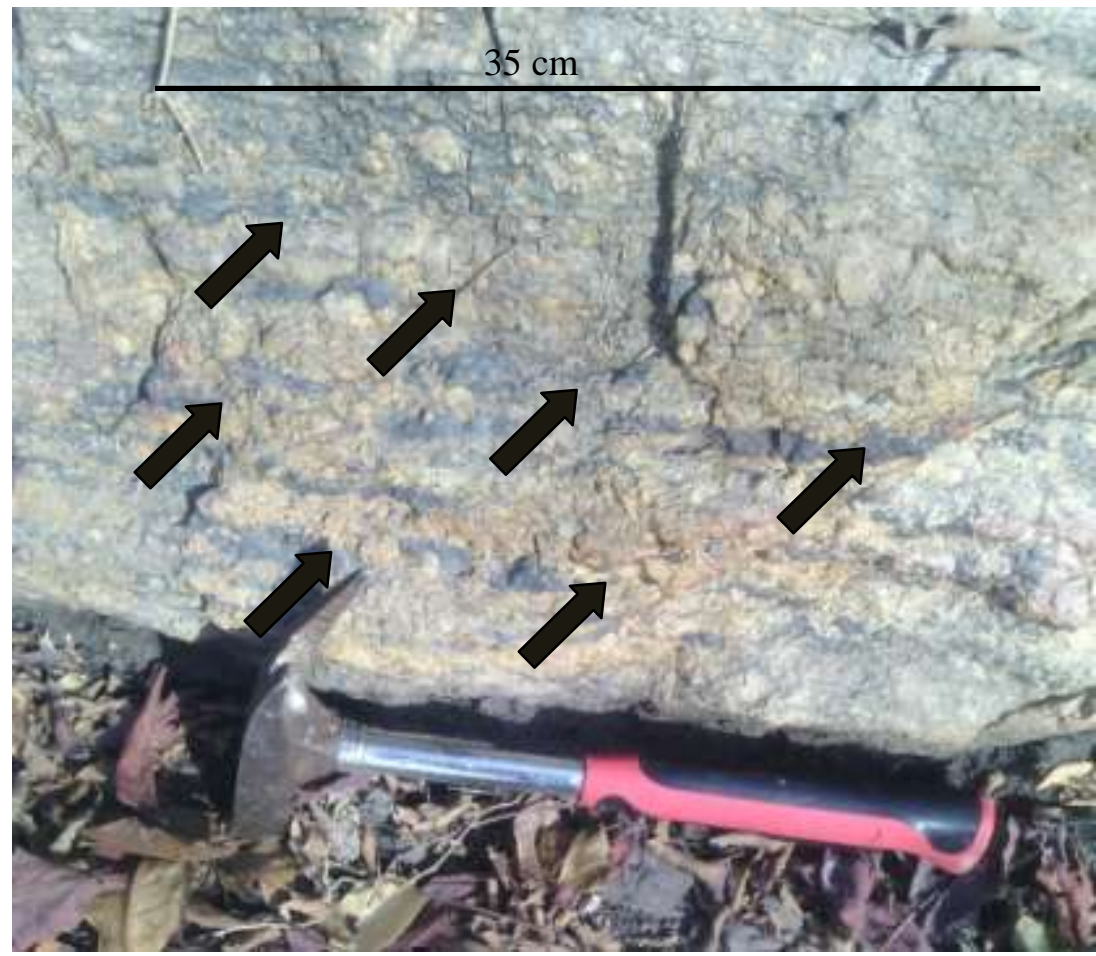

Plate I: magnetite mineralization (arrowed) in veins of granite-gneiss around sakla settlement of the study area. 


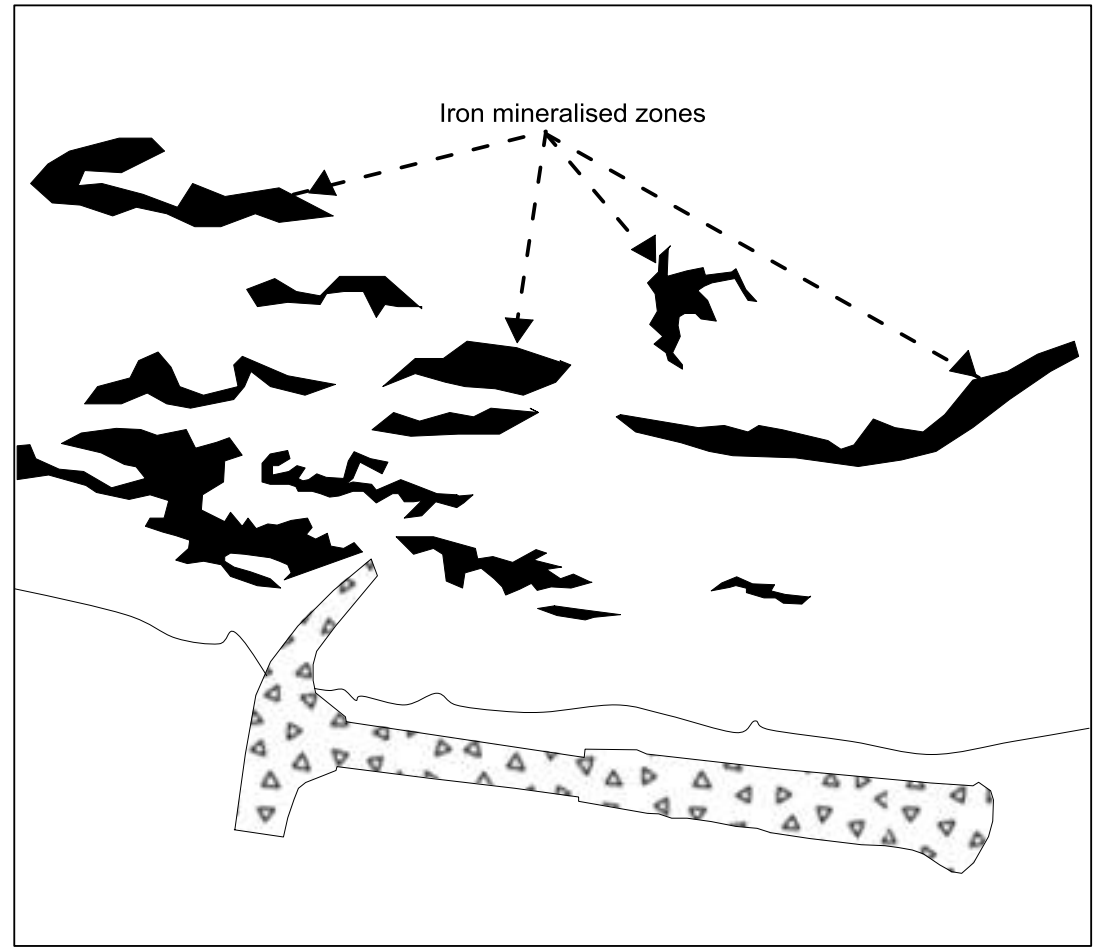

Figure 3: sketch of iron mineralized zone shown in plate i, above.

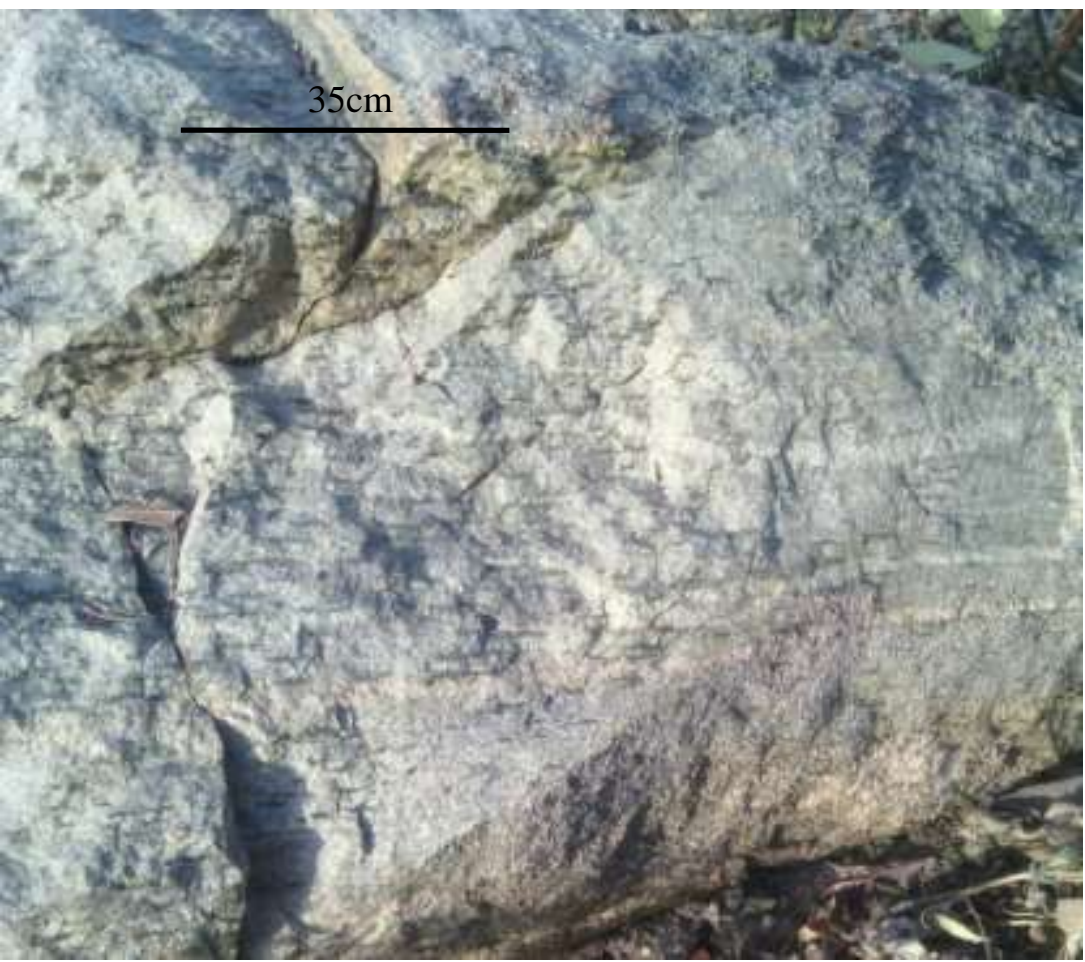

Plate ii: shows foliations in biotite hornblende gneiss in the study area.

\section{Geological Setting And Previous Magnetic Studies In The Adamawa Massifs}

Adamawa Massif, a sector of Nigeria's eastern Basement Complex is bounded by the Yola Trough to the north, Benue Rift to the West and Mamfe Embayment to the South. The rocks in the area include migmatitegneisses, granite-gneiss, porphyritic granite, porphyroblastic gneiss, and biotite -hornblende granites ([8], McCurry, [9], [10]). [11]Reported the occurrence of granodiorites, migmatites, porphyritic granites and fine grained granites with minor pegmatites in some areas of the Adamawa Basement complex. Based on petrological and mineralogical data, [11](op.cit.) reportedthat some granitiods (e.g the fine grained granites) which border the Benue Trough constitutes the immediate source rocks of the uranium mineral in Bima 
Sandstone within the Benue trough.Among the magnetic studies carried out on the Adamawa Basement Complex of northeastern Nigeria includes the work of [12] who interpreted magnetic anomalies over MutumBiyu areas in terms of dyke-like body with an average width of $0.7 \mathrm{Km}$ and an average depth of $0.3 \mathrm{Km}$. Also [13], analyzed aeromagnetic data over Mutum-Biyu and environs in the Adamawa massif by employing spectral analysis and Hilbert transformation of the data in the area, they found two magnetic source depth, which account for deeper and shallower sources. The deeper source, which they interpreted as originating from basement, varies from $661 \mathrm{~m}$ to $2722 \mathrm{~m}$. While the shallower magnetic sources interpreted as near surface intrusions with depth from 137 to $590 \mathrm{~m}$. [14], carried out a geological interpretation of an aeromagnetic maps of Jalingo and Monkin areas of the Adamawa massifs and reported the occurrence of lineaments oriented in a N-S, NE-SW, EW, NW - SE direction, with NE-SW direction dominating the study area, which is in conformity with the dominant regional structural trends in the area.

\section{Magnetic Field Data Acquisition And Processing}

The magnetic data over the study area were acquired using G-856-Mag ${ }^{T M}$ protonprecision magnetometer (Plate III) along profiles using the loop system, and along intersecting grid lines (Fig.4). The distance between stations was $0.852 \mathrm{~km}$, which is equivalent to one minute $\left(1^{\prime}\right)$ interval on the topographical map of the area. The length of each profile surveyed is $3.41 \mathrm{~km}$. The stations interval was selected in order to have a moderate number of stations, and make the data acquisition exercise completed within the available time. There was a base station, which was located at a chosen geomagnetic reference point close to the study area, and this was used in monitoring diurnal variations. Measurements were taken at the base station at the beginning of the survey and it was reoccupied in less than one and half hours (1.5 hours) using a motor cycle. The data reduction and processing activities usually being employed, involves series of steps taken to isolate both signals and spurious noise from the data that are not related to the geology of the earth's crust. This process therefore, prepares the data set for interpretation by reducing the data to contain only signals relevant to the task. Once the earth's main magnetic field and the minor source effects are filtered from the observed magnetic field data through various data reduction and processing methods ([15]), the processed data series serves as an indicator of the spatial distribution and concentration of the magnetically significant minerals. At this stage, the data are enhanced and presented in readiness for their analysis [16].

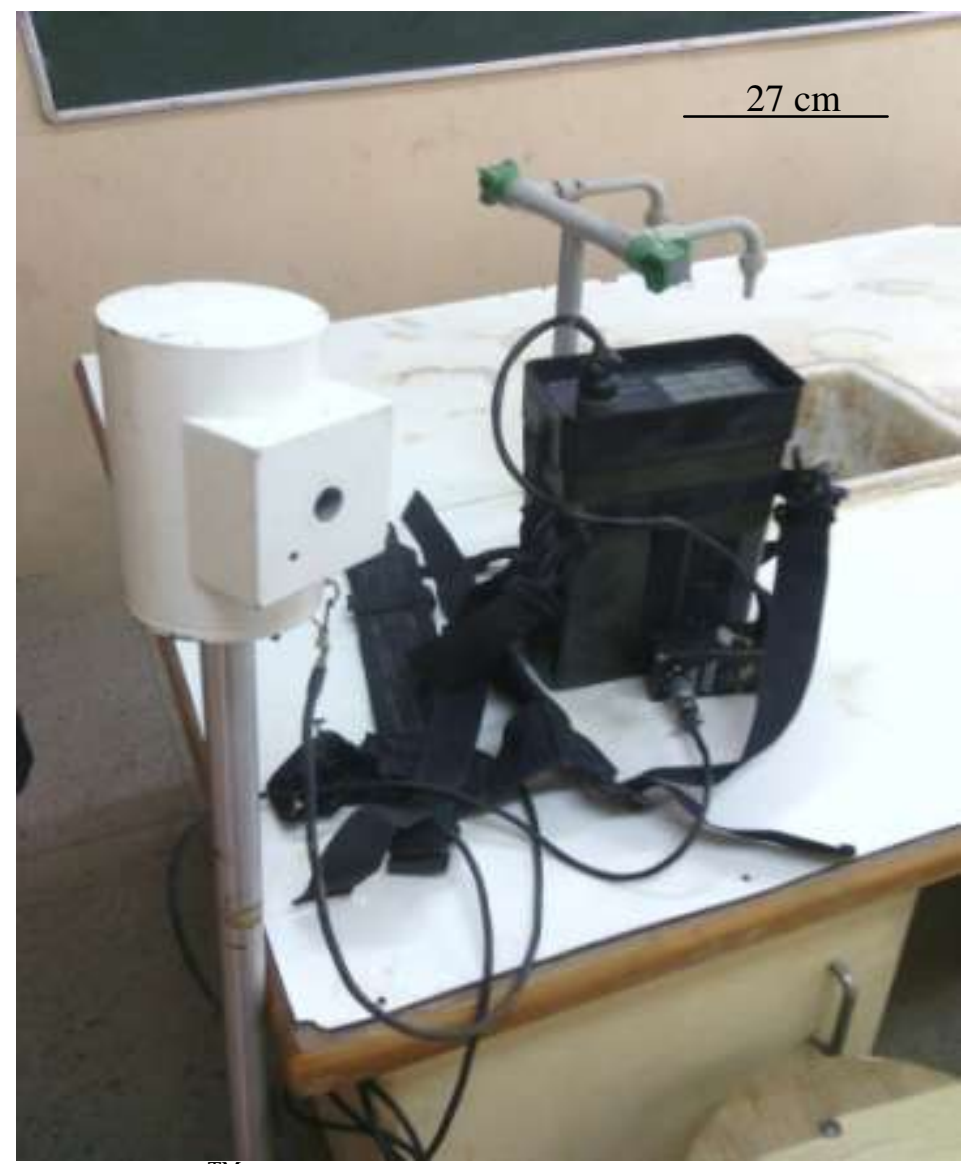

Plate III: Shows the G-856-Mag ${ }^{\mathrm{TM}}$ ProtonPrecision Magnetometer used for the magnetic data acquisition. 


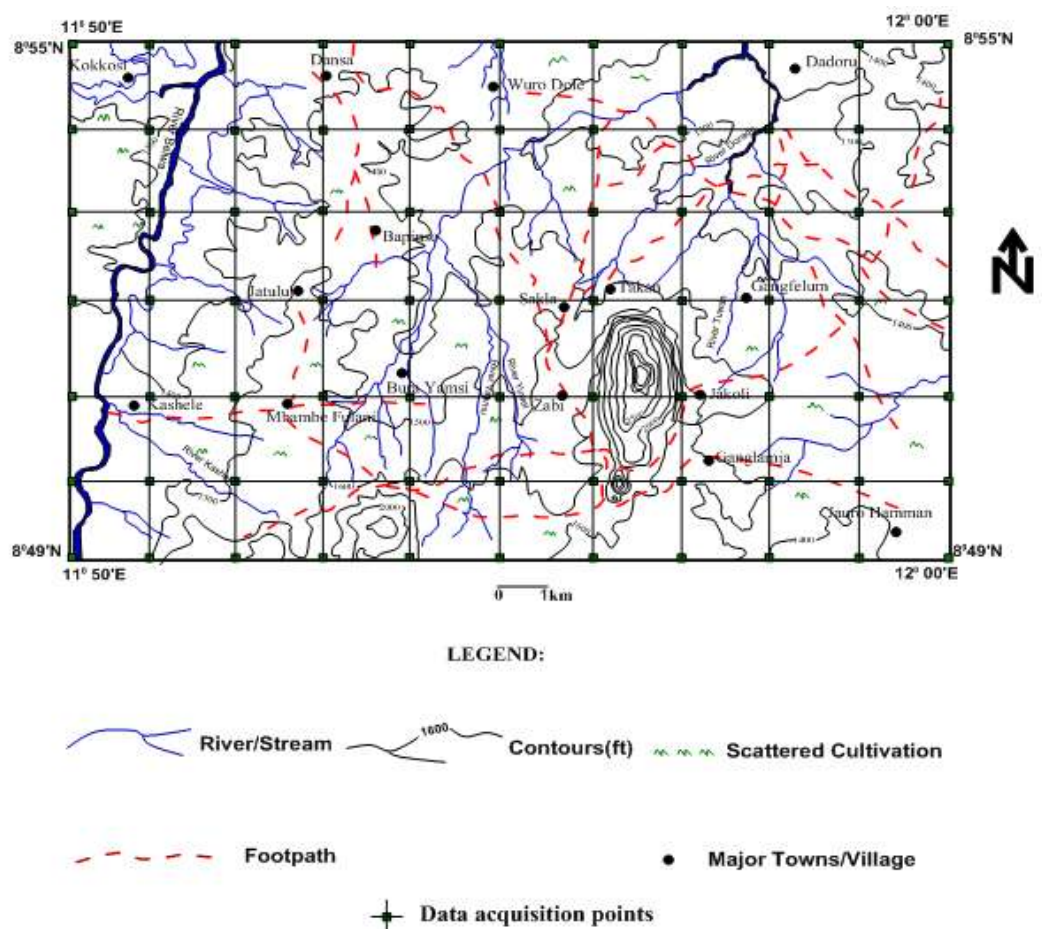

Figure 4: Gridded Topographic Map of the Study Area used in Magnetic Data Acquisition.

\section{DuirnalCorrection}

Data obtained from the field were subjected to diurnal correction (Table 1). This correction is done in order to remove the effect of diurnal variation on the magnetic data. This effect was removed by finding the differences observed in the base station and then distribute it among the readings at stations occupied during the day according to the time of observations, where the change is positive, the correcting factor is then subtracted from the field data acquired across all the stations found within that loop, and where the change is negative, it is then added from the field data acquired across all the stations found within that loop [17]. The diurnally corrected data were then used to plot the total magnetic field intensity (TMI) map of the study area using WingLink software.

\section{Regional - Residual Separation}

The Software - based means of separating regional field from the residual field was employed, the reduced potential field data were subjected to Polynomial fitting processing using Wing link software.

Table 1: Magnetic data corrected against diurnal variation

\begin{tabular}{|c|c|c|c|c|c|c|c|}
\hline \multirow[t]{2}{*}{$\mathbf{S} / \mathbf{N}$} & \multicolumn{2}{|c|}{ COORDINATES } & \multirow[t]{2}{*}{ TIME } & \multirow{2}{*}{$\begin{array}{l}\text { MAGNETIC } \\
\text { READING }\end{array}$} & \multirow{2}{*}{$\begin{array}{c}\text { BASE STATION } \\
\text { VALUE }\end{array}$} & \multirow{2}{*}{$\begin{array}{l}\text { CORRECTED } \\
\text { READINGS }\end{array}$} & \multirow[t]{2}{*}{ DATE } \\
\hline & EASTINGS & NORTHINGS & & & & & \\
\hline 1 & $11^{\circ} 59^{\prime} 00^{\prime \prime}$ & $8^{\circ} 55^{\prime} 00^{\prime \prime}$ & $7: 15$ & 34326 & & 34325.1 & $"$ \\
\hline 3 & $11^{\circ} 57^{\prime} 00^{\prime \prime}$ & $8^{\circ} 55^{\prime} 00^{\prime \prime}$ & $7: 45$ & 34327 & & 34325.8 & $"$ \\
\hline 4 & $11^{\circ} 56^{\prime} 00^{\prime \prime}$ & $8^{\circ} 55^{\prime} 00^{\prime \prime}$ & $8: 02$ & 34332 & & 34331.0 & $"$ \\
\hline 5 & $11^{\circ} 55^{\prime} 00^{\prime \prime}$ & $5^{\circ} 55^{\prime} 00^{\prime \prime}$ & $8: 10$ & 34333 & & 34332.0 & $"$ \\
\hline BASE: & $12^{\circ} 00^{\prime} 00^{\prime \prime}$ & $8^{\circ} 55^{\prime} 00^{\prime \prime}$ & $8: 32$ & & 34331 & & " \\
\hline 7 & $11^{\circ} 53^{\prime} 00^{\prime \prime}$ & $8^{\circ} 55^{\prime} 00^{\prime \prime}$ & 9:01 & 34337 & & 34338.8 & $"$ \\
\hline 8 & $11^{\circ} 52^{\prime} 00^{\prime \prime}$ & $8^{\circ} 55^{\prime} 00^{\prime \prime}$ & $9: 14$ & 34336 & & 34336.6 & $"$ \\
\hline 9 & $11^{\circ} 51^{\prime} 00^{\prime \prime}$ & $8^{\circ} 55^{\prime} 00^{\prime \prime}$ & $9: 29$ & 34333 & & 34333.6 & $"$ \\
\hline 10 & $11^{\circ} 50^{\prime} 00^{\prime \prime}$ & $8^{\circ} 55^{\prime} 00^{\prime \prime}$ & $9: 39$ & 34329 & & 34329.7 & $"$ \\
\hline 11 & $11^{\circ} 50^{\prime} 00^{\prime \prime}$ & $8^{\circ} 54^{\prime} 00^{\prime \prime}$ & $9: 45$ & 34322 & & 34322.6 & $"$ \\
\hline 14 & $11^{\circ} 53^{\prime} 00^{\prime \prime}$ & $8^{\circ} 54^{\prime} 00^{\prime \prime}$ & $10: 45$ & 34339 & & 34339.1 & $"$ \\
\hline 15 & $11^{\circ} 54^{\prime} 00^{\prime \prime}$ & $8^{\circ} 54^{\prime} 00^{\prime \prime}$ & 11:00 & 34341 & & 34341.8 & " \\
\hline 16 & $11^{\circ} 55^{\prime} 00^{\prime \prime}$ & $8^{\circ} 54^{\prime} 00^{\prime \prime}$ & $11: 10$ & 34333 & & 34333.9 & $"$ \\
\hline 17 & $11^{\circ} 56^{\prime} 00^{\prime \prime}$ & $8^{\circ} 54^{\prime} 00^{\prime \prime}$ & $11: 18$ & 34331 & & 34331.9 & $"$ \\
\hline 18 & $11^{\circ} 57^{\prime} 00^{\prime \prime}$ & $8^{\circ} 54^{\prime} 00^{\prime \prime}$ & $11: 26$ & 34334 & & 34334.8 & $"$ \\
\hline
\end{tabular}


Ground Magnetic Investigation Of Iron Occurrence In The Basement Rocks Ofdadoru And Environs,

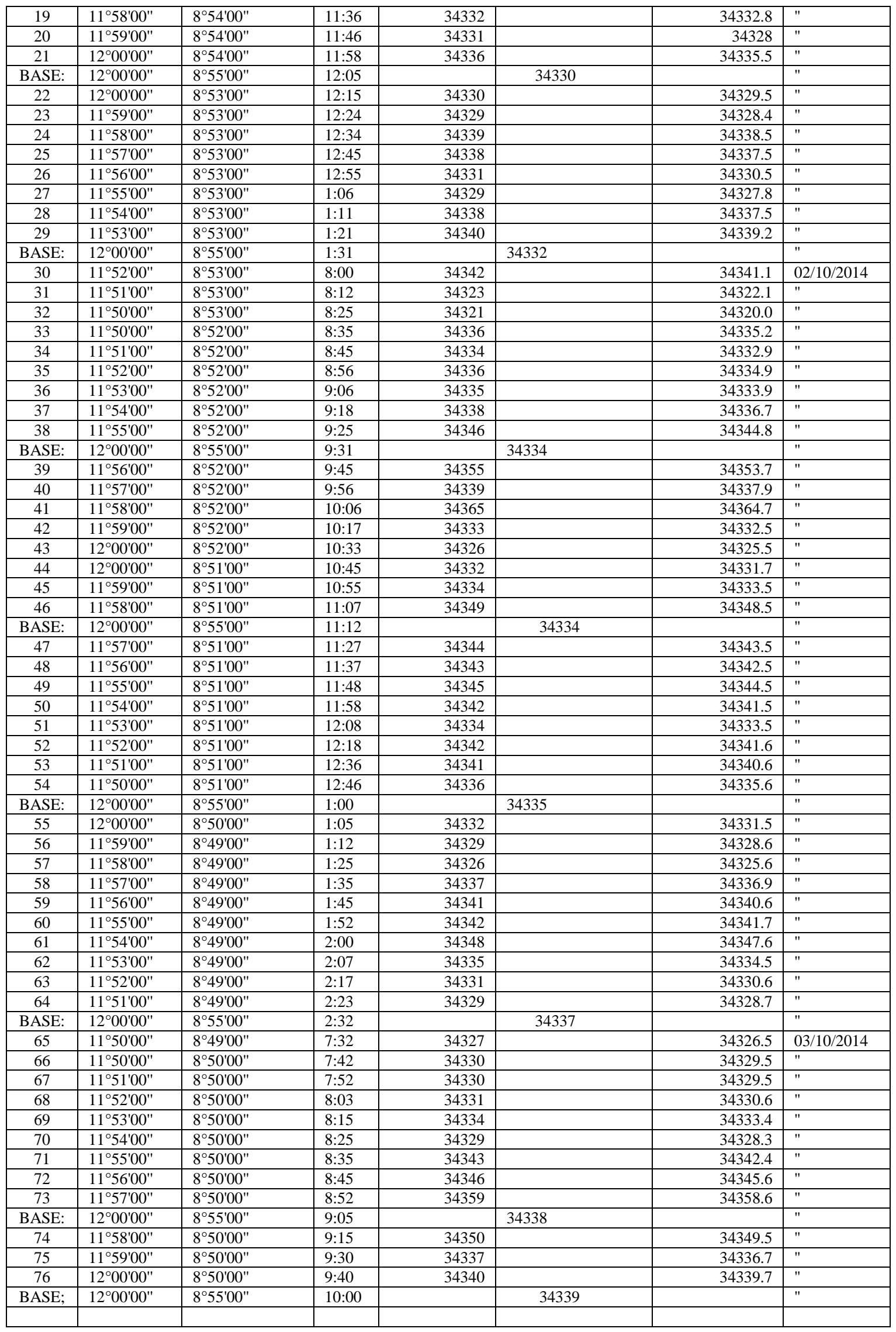




\section{Polynomial Fitting}

The Total Magnetic Intensity (TMI) data when subjected to polynomial fitting processing, it separates residuals from regional field. Features produced by shallow geological bodies are enhanced and appears clearer and more visible. In this method of regional - residual separation, the regional is represented by mathematical polynomial of low order to expose the residual features as random errors. The treatment is based on statistical theory, and practically, the polynomial rarely exceeds 2nd order. In the case of the present work, polynomial of second order was used (Figure 5). The choice of polynomial order depends on the complexity of the regional geology. If the regional field were simple incline plane, it will be a first order of the form;

$\mathrm{Z}=\mathrm{Ax}+\mathrm{By}+\mathrm{C}$

The next level of complexity of the regional field is represented by polynomials of second order;

$\mathrm{Z}=\mathrm{Ax}^{2}+\mathrm{By}^{2}+\mathrm{Cxy}+\mathrm{Dx}+\mathrm{Ey}+\mathrm{F}$

Polynomials of higher order will be necessary for a large area over which the regional has numerous convolutions.

\section{Results And Discussion}

Areas characterized by the predominance of short wavelength, high gradient and high amplitude anomalies from both total field magnetic intensity map (Fig.5), and the polynomial fitting map (Fig.6) of the study area includes: Gangfelum, Sakla, Takan, Jatulu, and Dansa settlements of the study area. Whereas those with long wavelength, low gradient, low amplitude anomalies (34338nT - 34320nT) interpreted as being from the deeper sources follow the Northeast - Southwest direction and located in between Jatulu and Kokkosi settlement in the western part of the TMI map of the study area.Areas characterized by short wavelength / high gradient anomalies (34342nT -34348nT) mentioned earlier are interpreted as being produced by intrusions of iron minerals which are also considered to be located at shallow depth within the crystalline Basement rocks in the study area. This is in conformity with [13], who interpreted shallower magnetic source from aeromagnetic data as being produce by near surface intrusions that varies from $137 \mathrm{~m}$ to $590 \mathrm{~m}$ around "Mutum - Biyu" areas which lies west of the present area of study.

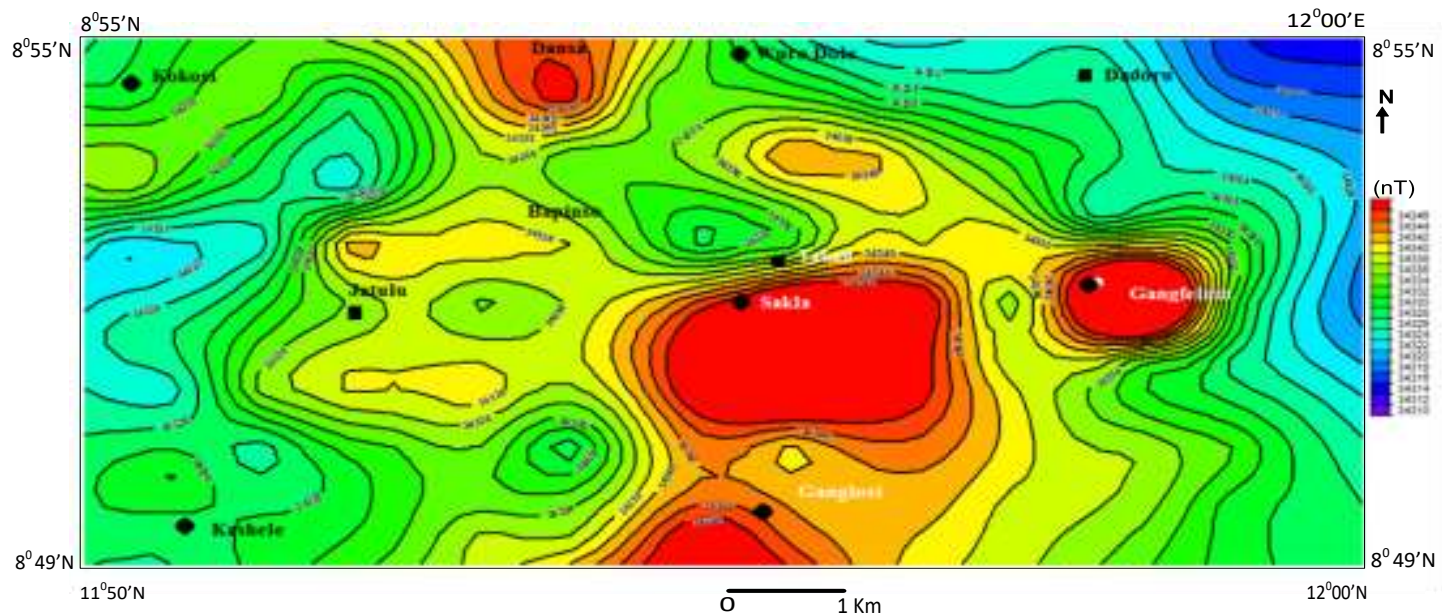

Figure 5: Total Magnetic Field Intensity (TMI) Map of the Study Area (contour interval: 2 nT)

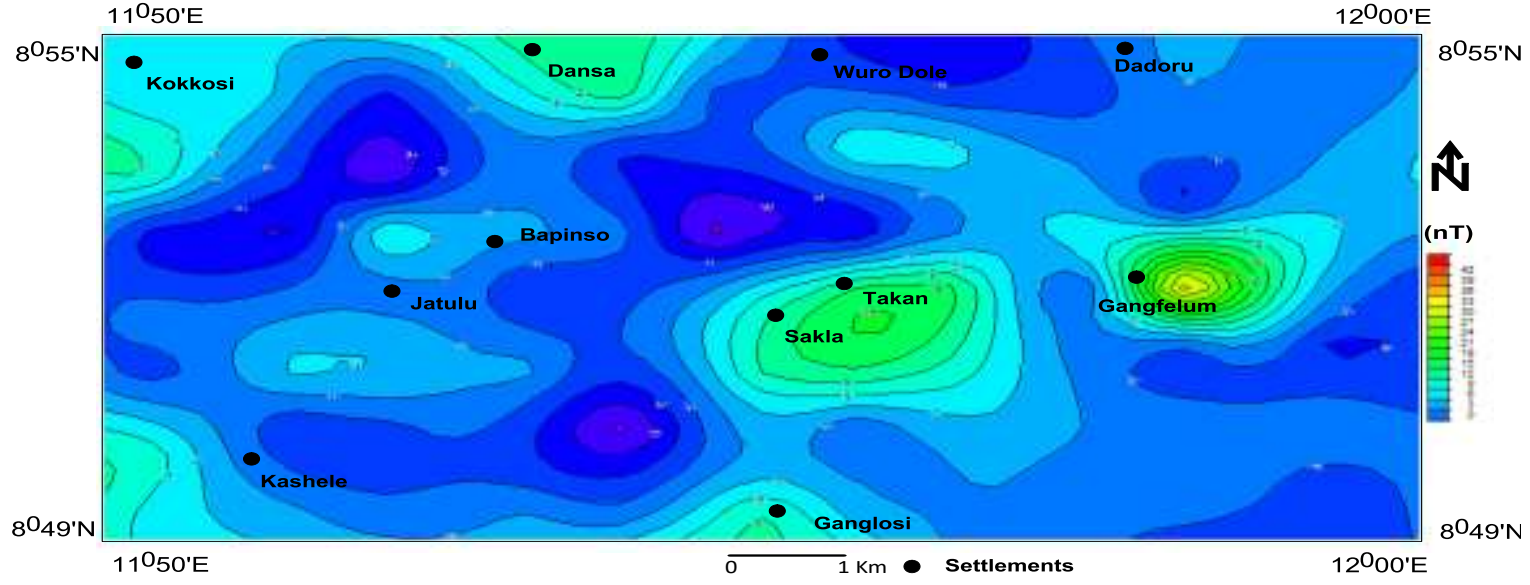

Figure 6: Polynomial ( $2^{\text {nd }}$ degree) Map of the Study Area (cont. Int. 3.0 nT) 


\section{$X$. Profiles models}

A number of profiles labeled (AA' - FF') were drawn across some selected anomalies on the total magnetic field intensity map (TMI) of the study area as shown in Fig.7, and in a direction perpendicular to the major strike direction of the selected anomalies. The selected profiles were modeled and shown in Figures; 8, 9, $10,11,12$, and 13. The estimated depth to the source of magnetic anomalies (iron ores) is shown in Table 2 . All magnetic profiles were modelled to have iron intrusions except $\mathrm{F}-\mathrm{F}$ ' which is modeled as a fault. The modelling was by curve matching, by generating profiles until the generated profiles made the best fit with the field profiles respectively. Susceptibilities were generated by the software used for the modeling. Moreover, upon considering profile models ( $\mathrm{A}-\mathrm{A}^{\prime}$ to $\left.\mathrm{F}-\mathrm{F}^{\prime}\right)$, it is seen that, profile $\mathrm{A}-\mathrm{A}^{\prime}$ has the highest value of estimated depth to the source of magnetic anomaly of $560 \mathrm{~m}$ while profile $\mathrm{F}-\mathrm{F}^{\prime}$ is having the least value of magnetic source depth (see: Table 2) and the average depth to the source of magnetic anomaly is given as $351.67 \mathrm{~m}$.

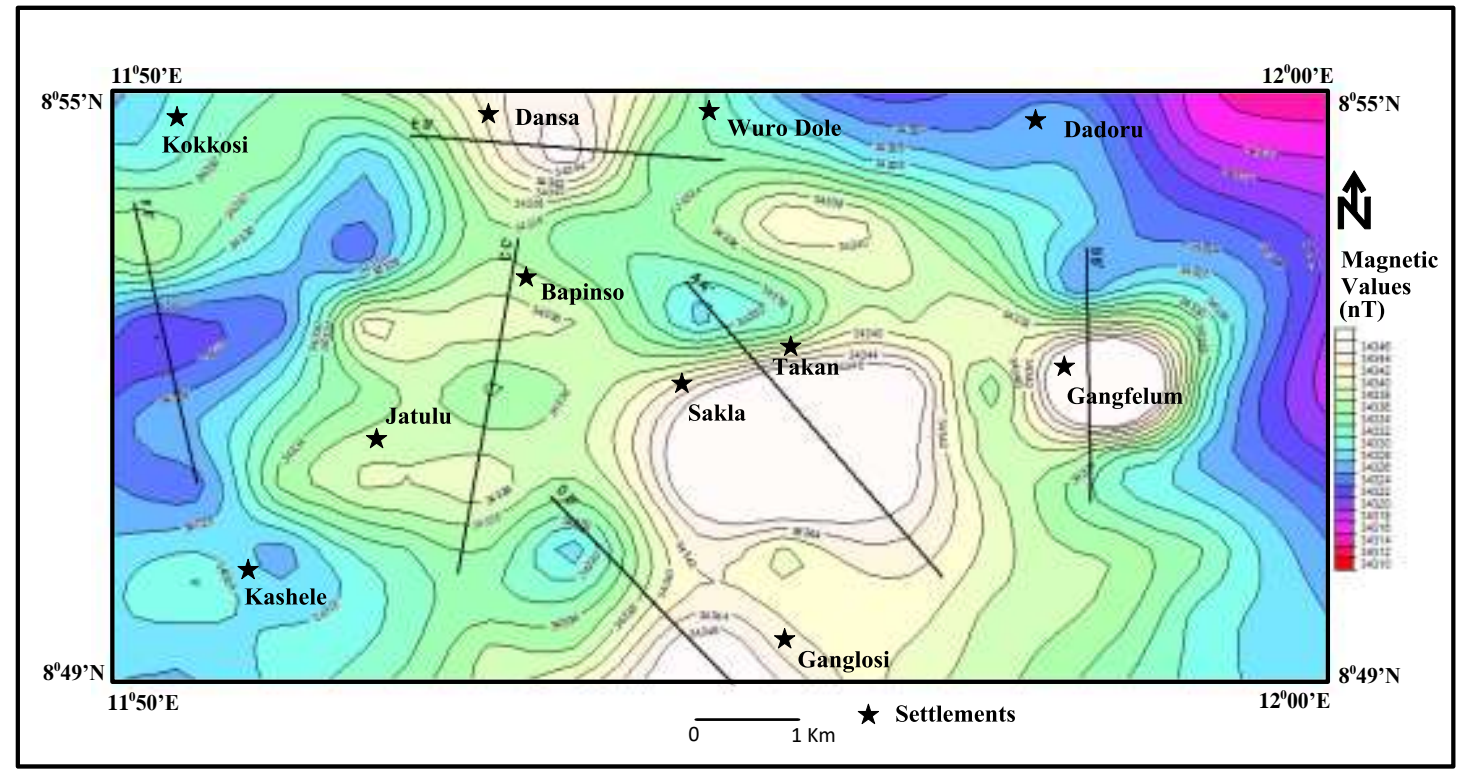

Figure 7.Total Field Magnetic Intensity Map of the Study Area with Profiles ( AA' - F - F').

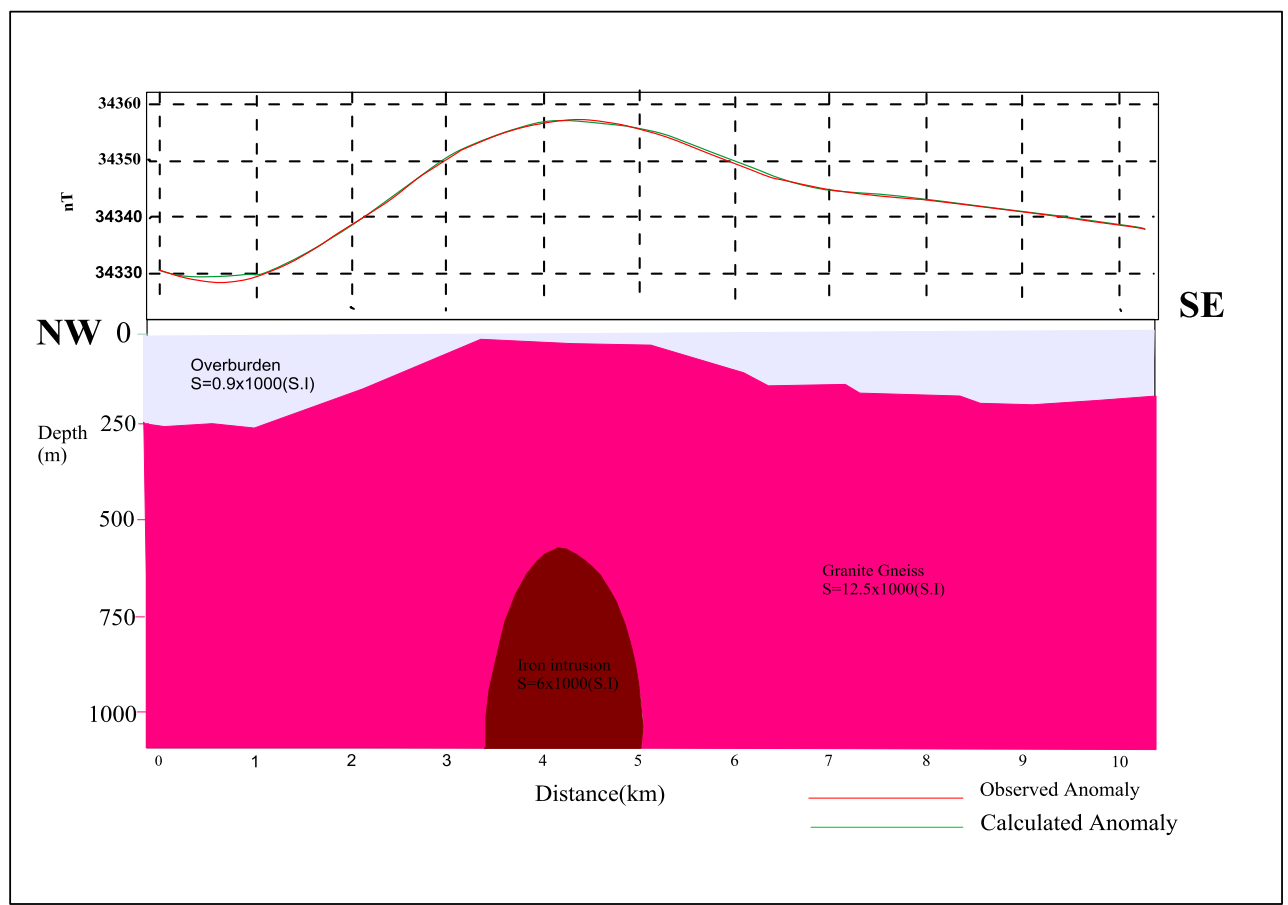

Figure8. Geomagnetic Section along Profile A - A’ of the Study Area 


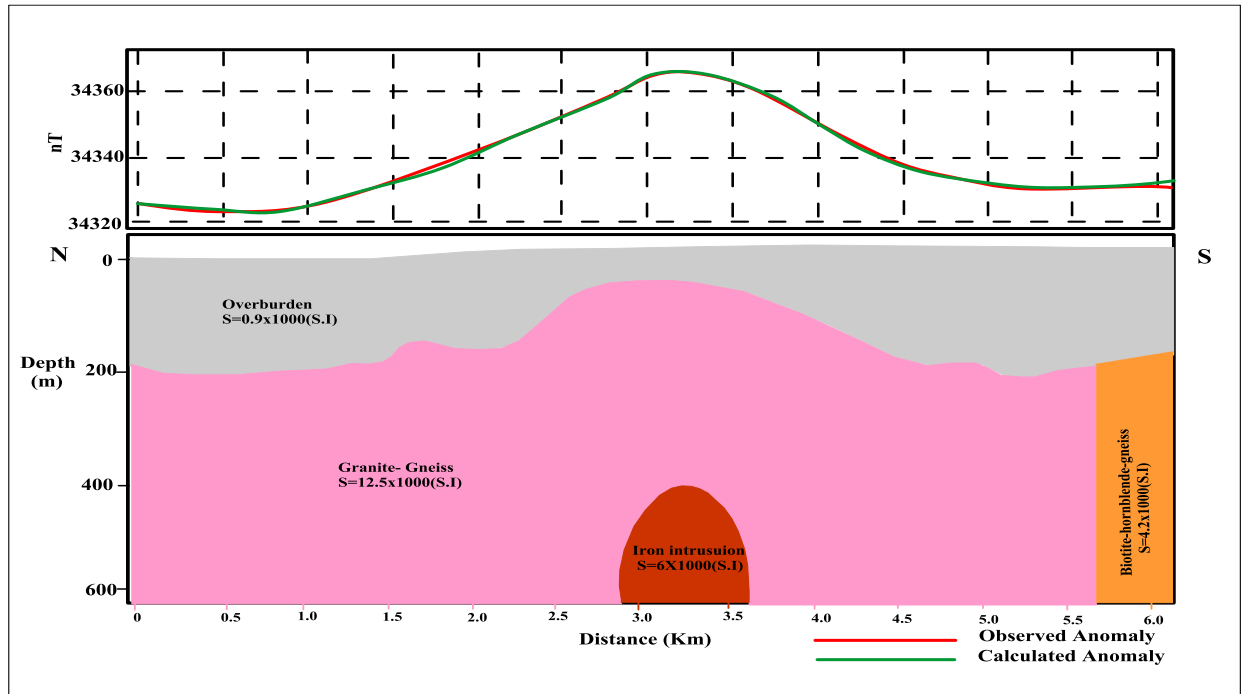

Figure 9.Geomagnetic Section along Profile B - B' of the Study Area

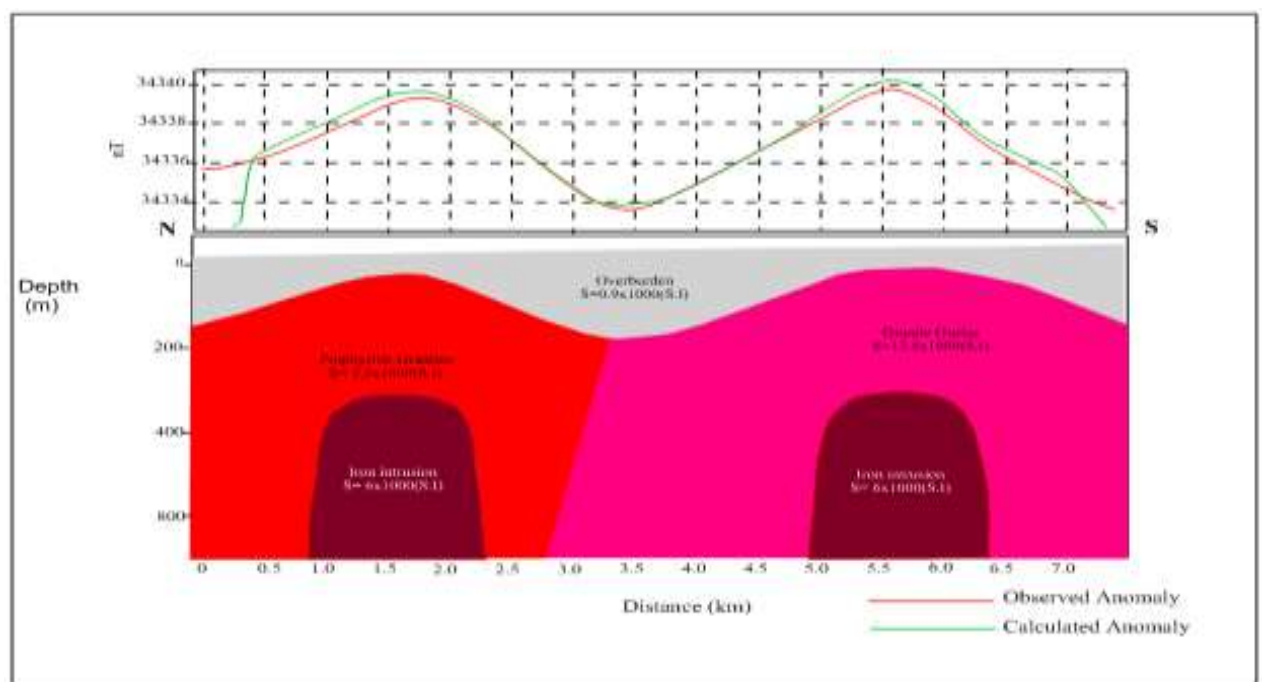

Figure10. Geomagnetic Section along Profiles $\mathrm{C}-\mathrm{C}$ ' of the study Area

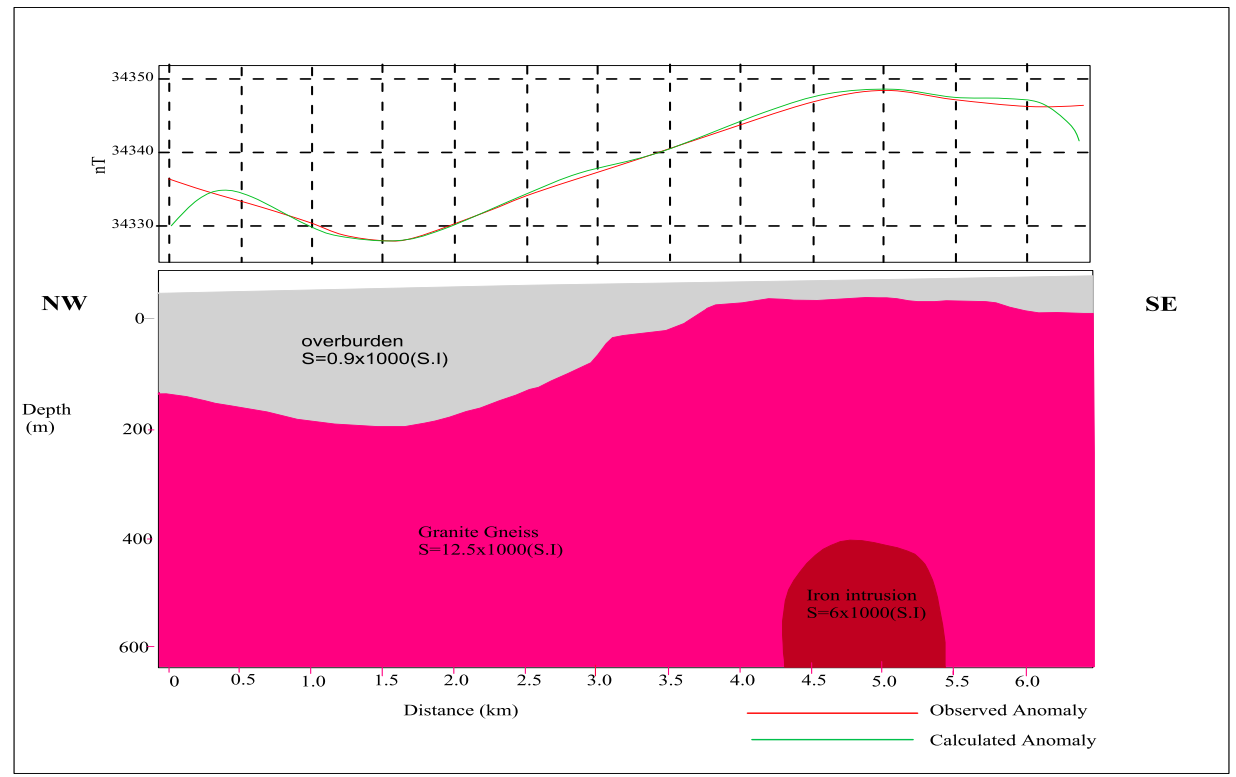

Figure11. Geomagnetic Section along Profile D - D' of the Study Area. 


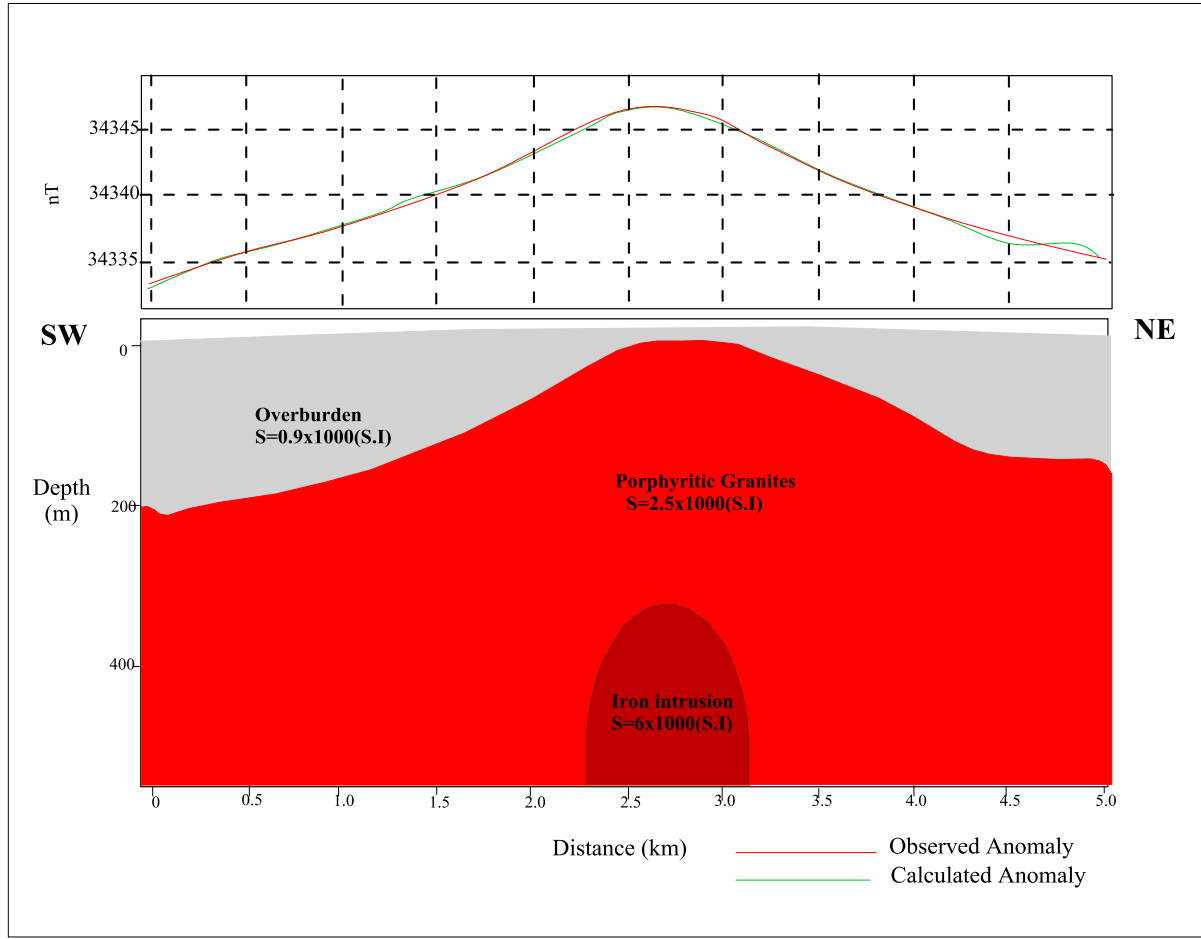

Figure12. Geomagnetic Section along Profile E - E' of the Study Area.

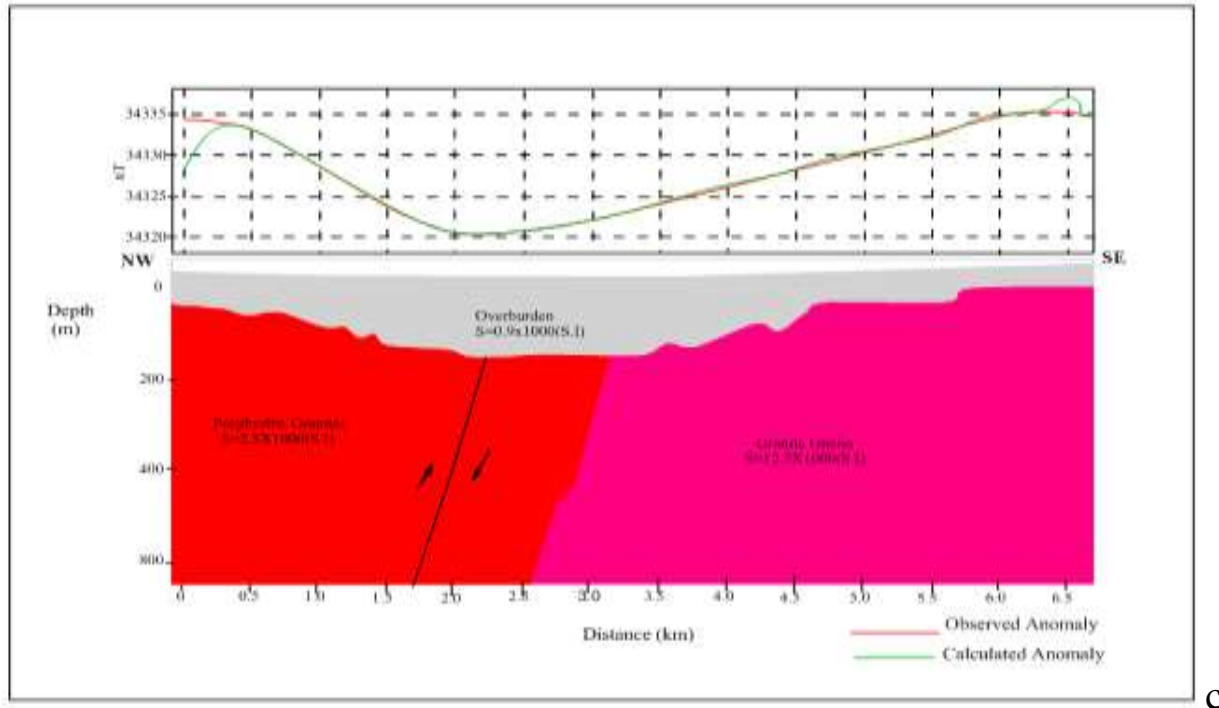

Figure 13.Geomagnetic Section along Profile F - F’ of the Study Area.

Table 2: Summary of estimated depth to the sources of anomalous bodies

\begin{tabular}{ccc} 
S/N & Profiles & Estimated depth (m) \\
\hline 1 & A - A & 560 \\
2 & B - B' & 390 \\
3 & C - C' & 300 \\
4 & D - D' & 400 \\
5 & E - E' & 300 \\
6 & F - F' & 160
\end{tabular}

The average depth to magnetic source of anomaly is given as; $351.67 \mathrm{~m}$. 


\section{Conclusion}

Geological field studies of the area revealed that the area is underlain by older granite suites which include porphyritic granites, granite gneiss, and biotite hornblende gneiss. Field structural studies also revealed the occurrence of joints, faults, mineralized (Iron) veins, Areas characterized by higher magnetic anomalies such as; Gangfelum, Sakla, Takan, Jatulu and Dansa are considered to be the major areas underlain by iron mineralization. Subsurface models of geomagnetic sections yielded an average depth of $351.67 \mathrm{~m}$ to magnetic bodies. Surface geological mapping shows the iron to occur as mineralized veins in granite gneiss and porphyritic granites. A geological follow up for tenor and tonnage estimation of the discovered iron mineral should be done by appropriate mining company/agency to see the possibility of its exploitation.

\section{References.}

[1] Federal Surveys Agency of Nigeria, 1976. Topographic Sheet 216, Monkin NE, Nigeria. Scale: 1: 100,000

[2] Horsfall, K.R., 1997. Airborne Magnetic and Gamma - Ray data acquisition. AGSO Journal of Geology and Geophysics 17: 23 30

[3] Merrill, R.T., MmEthinny, M.W. and McFadden, P.L., 1996. The Magnetic field of the earth: Paleomagnetism, the core and the deep mantle. Academic Press, San Diego, 531pp.

[4] Doell, R. and Cox, A., 1967: Magnetisation of Rocks. In: SEG Mining Geophysics Volume Editorial Committee (Editors), Mining Geophysics. Volume 2 : Theory. Society of Exploration Geophysicists, Tulsa.Pp.446-453.

[5] Telford, W.M., Geldert, L.P., Sheriff, R.E., and Keys, D.A., 1990. Applied Geophysics, Cambridge University Press, Cambridge, $74-78$ pp.

[6] Clarke, D.A., 1997. Magnetic Petrophysics and Magnetic Petrology: aids to Geological Interpretation of magnetic Surveys. AGSO Journal of Geology and Geophysics 17: $83-103$.

[7] Kogbe, C.A. 1989. Geology of Nigeria ( $2^{\text {nd }}$ Edition). Rock view Nigeria Limited Jos, Plateau State. Pp1 - 538.

[8] Rahaman, M.A., 1976. Review of Basement Geology of Southwestern Nigeria. In: C.A. Kogbe, (ed.), Geology of Nigeria.ElizabethanPublishing Company, Lagos, pp. 41-58.

[9] McCurry, P., 1971. Pan African Orogeny in Northern Nigeria. In: Ekwueme, B.N., 1987 Structural features of Southern Obudu Plateau, Bamenda Massif, S.E.Nigeria. Journal of Mining and Geology, vol.30, No.1, pp.45-59

[10] Oyawoye, M.O., 1970. The Basement complex of Nigeria In: Dessauvagie. T.F.J. and Whiteman, A.J.W. (eds.) African Geology, University of Ibadan press, pp.67-99.

[11] Haruna, I.V., Orazulike, D.M., Ofulume, A.B., 2011. Some Petrological and Mineralogical Constraints on the Source and Processes for Uranium Mineralisation on the Granitoids of Zing - Monkinareas. Global Journal of Geological Sciences.Vol.9(2).

[12] Ofoegbu, C.O., 1985. Interpretation of a Linear Magnetic Features near Mutum - Biyu, Northeast, NgeriaRevistaBrazilleira de Geofisica. Vol.3. pp.91-97.

[13] Kasidi, S., and A. Nur., 2012. Analysis of Aeromagnetic data Over Mutum-biyu and environs, Northeastern Nigeria. Research Journal of Engineering and Applied Science., $1: 142$ - 148.

[14] Bappah, A.A., 2009. Geological Interpretation of Aeromagnetic Maps of Jalingo and Monkin areas of the Adamawa massifs, Northeastern Nigeria. Unpublished M.sc Thesis, Federal University of Technology Yola, Adamawa state, Nigeria.

[15] Luyendyke, A.P.J., 1997. Processing of Airborne magnetic data. AGSO Journal Geology and Geophysics. 17: p 31-38.

[16] Milligan, P.R and Gunn, P.J., 1997. Enhancement and presentation of Airborne geophysical data. AGSO Journal Geology and Geophysics.17: p 63-75.

[17] Dobrin, M. 1976. Introduction to geophysical prospecting ( $3^{\text {rd }}$ edition).McGraw Hill Book Co. 